\title{
Advanced practice registered nurses, physician assistants and cancer prevention and screening: a systematic review
}

\author{
Alexandria A Smith', Deanna Kepka ${ }^{2,3,4^{*}}$ and K Robin Yabroff $^{2}$
}

\begin{abstract}
Background: For more than two decades, integration of team-based approaches in primary care, including physicians, advanced practice registered nurses and physician assistants (APRN/PA), have been recommended for improving healthcare delivery, yet little is known about their roles in cancer screening and prevention. This study aims to review the current literature on the participation and roles of APRN/PAs in providing cancer screening and prevention recommendations in primary care settings in the United States.

Methods: We searched MEDLINE and CINAHL to identify studies published in 1990-2011 reporting on cervical, breast, and colorectal cancer screening and smoking cessation, diet, and physical activity recommendations by APRN/PAs in the United States. A total of 15 studies met all of our eligibility criteria. Key study, provider, and patient characteristics were abstracted as were findings about APRN/PA recommendations for screening and prevention.
\end{abstract}

Results: Most studies were cross-sectional, showed results from within a single city or state, had relatively small sample sizes, reported non-standardized outcome measures. Few studies reported any patient characteristics. APRN/PAs are involved in recommending cancer screening and prevention, although we found variation across screening tests and health behavior recommendations.

Conclusions: Additional research on the cancer prevention and screening practices of APRN/PAs in primary care settings using standardized outcome measures in relation to evidence-based guidelines may help strengthen primary care delivery in the United States.

\section{Background}

In the United States (US), cancer is the second leading cause of death [1]. According to current US Preventative Services Task Force (USPSTF) practice guidelines, cancer screening is associated with reduced cervical, breast, and colorectal cancer mortality and efforts to promote tobacco cessation [2-4], a healthful diet, and increased physical activity are associated with reduced cancer risk [5]. Yet in some populations with historically poor cancer outcomes, particularly the uninsured, low-income, and minorities [6,7], these evidence-based cancer control interventions have not been fully adopted [8]. The Affordable

\footnotetext{
* Correspondence: deanna.Kepka@hci.utah.edu

${ }^{2}$ Division of Cancer Control and Population Sciences, National Cancer Institute, Bethesda, MD, USA

${ }^{3}$ College of Nursing, University of Utah, Salt Lake City, UT

Full list of author information is available at the end of the article
}

Care Act will give approximately 32 million Americans greater access to healthcare and specifically the aforementioned cancer screening and prevention methods without any copayment by $2014[9,10]$.

A recent Institute of Medicine Report (2011) called upon nurses to help meet the goals of the Affordable Care Act and outlined state and federal policy strategies to help ensure that nurses practice to the full extent of their education and training. For example, because APRN/PAs are not consistently able to see patients and provide medications without a physician's supervision, the report calls for reform of states' scope-of-practice laws. Furthermore, this report calls on nurses to serve as full partners with physicians and other healthcare professionals in the redesign of the US healthcare system and provides educational opportunities [11]. In addition,

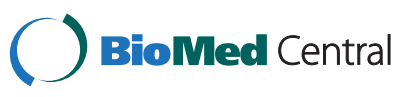


the Affordable Care Act provides for the Expansion of Physician Assistant Training Program [12], aims to increase student enrollment in primary care Physician Assistant (PA) programs. Since 1990 the number of APRN/PAs working in the US has risen from 50,000 to 250,000 in 2010, with midlevel providers conducting an increasing role in serving underserved populations and locations $[13,14]$. Approximately 55\% APRNs/PAs work in a primary care setting [15]. The US Bureau of Labor Statistics reports that physician assistants within the United States are expected to grow by 30\% between 2010 and 2020 [16]. Thus, this growing cadre of primary care health professionals is uniquely positioned to meet the growing demand for primary care resulting from the expansion of healthcare coverage by the Affordable Care Act.

As more individuals enter into the health care system, widespread implementation of evidence-based cancer screening and prevention interventions is critical for reducing cancer mortality and morbidity, but taxing on an already burdened healthcare system. In order to fulfill all of the current US Preventative Services Task Force recommendations for an average size patient panel, a primary care provider would exhaust an estimated 7.4 hours each day before providing diagnoses, treatments, or conducting administrative tasks [17]. Advanced practice nurses and physician assistants (APRN/PAs), including Nurse Practitioners (NPs), Physicians Assistants (PAs), and Certified Nurse Midwives (CNMs) are positioned to help meet this demand for recommended preventive services. For more than two decades, recommendations have been made to include APRN/PAs within primary care teams to improve chronic care delivery systems [18-21]. However, little is known about the roles of APRN/PAs in cancer screening and prevention, or how they might help meet an increasing demand for care. In this study, we conducted a systematic review of the recently published literature to assess the recommendations for and provision of USPSTF recommended cancer prevention and screening by APRN/PAs in primary care settings.

\section{Methods}

\section{Study selection}

We used the PubMed search mechanism for MEDLINE and CINAHL to identify English language studies on USPSTF recommended cancer prevention and screening recommendations among APRN/PAs in the United States published between January 1990 and December 2011. The search strategy used a combination of NIH librarian recommended terms that addressed APRN/PAs, cervical, breast, or colorectal cancer screening or recommendations for smoking cessation, or diet and physical activity. Using the following combination of search terms, a total of 594 studies were found: "Early Detection of Cancer" or "Vaginal Smears" or "Mammography" or "Breast Neoplasms/prevention and control" or "Colorectal Neoplasms/prevention and control" or "Mass Screening" or "Papillomavirus Vaccines" and "Diet" or "Exercise" or "Motor Activity" or "Tobacco Use Cessation" and "Counseling" or "Nurse's Role" or "Preventive Health Services" or "Patient Acceptance of Health Care" or "Patient Education as Topic" or "Health Knowledge, Attitudes, Practice" and "Nurse Practitioners" or "Physician Assistants" or "Nurse Midwives". Organization of search terms and the number of published studies identified with each set of terms can be found in Table 1 .

Abstracts were reviewed to identify the type of cancer screening or prevention, study design, sample size, and the country where the study was conducted. Inclusion criteria for this review were studies reporting: APRN/ PAs conducting cancer prevention screening for cervical, breast or colorectal cancer, recommendations for smoking cessation, or diet and physical activity; United States

\section{Table 1 Search terms used in med line and CINAHL}

\begin{tabular}{|c|c|c|c|}
\hline $\begin{array}{l}\text { Group } \\
\text { number }\end{array}$ & Search term & $\begin{array}{l}\text { Number } \\
\text { of articles } \\
\text { medline }\end{array}$ & $\begin{array}{l}\text { Number } \\
\text { of articles } \\
\text { CINAHL }\end{array}$ \\
\hline \multirow[t]{3}{*}{ Group 1} & Nurse Practitioners OR & 22,644 & 3,779 \\
\hline & Physician Assistants OR & & \\
\hline & Nurse Midwives & & \\
\hline \multirow[t]{5}{*}{ Group 2} & "Counseling"[Mesh:noexp] OR & 576,608 & 9,166 \\
\hline & "Nurse's Role"[Mesh] OR & & \\
\hline & $\begin{array}{l}\text { "Patient Acceptance of Health } \\
\text { Care"[Mesh] OR }\end{array}$ & & \\
\hline & $\begin{array}{l}\text { "Patient Education as } \\
\text { Topic"[Mesh] OR }\end{array}$ & & \\
\hline & $\begin{array}{l}\text { "Health Knowledge, Attitudes, } \\
\text { Practice"[Mesh] }\end{array}$ & & \\
\hline \multirow[t]{4}{*}{ Group 3} & "Diet"[Mesh] OR & 335,235 & 52,213 \\
\hline & "Exercise"[Mesh] OR & & \\
\hline & "Motor Activity"[Mesh] OR & & \\
\hline & $\begin{array}{l}\text { "Tobacco Use } \\
\text { Cessation"[Mesh] }\end{array}$ & & \\
\hline \multirow[t]{8}{*}{ Group 4} & $\begin{array}{l}\text { "Early Detection of } \\
\text { Cancer"[Mesh] OR }\end{array}$ & 132,489 & 4,199 \\
\hline & "Vaginal Smears"[Mesh] OR & & \\
\hline & "Mammography"[Mesh] OR & & \\
\hline & $\begin{array}{l}\text { "Breast Neoplasms/prevention and } \\
\text { control"[Majr:noexp] OR }\end{array}$ & & \\
\hline & $\begin{array}{l}\text { "Colorectal Neoplasms/prevention } \\
\text { and control"[Maj:noexp] OR }\end{array}$ & & \\
\hline & "Mass Screening"[Mesh] OR & & \\
\hline & "Papillomavirus Vaccines"[Mesh] & & \\
\hline & $\begin{array}{l}\text { Group } 1 \text { and Group } 2 \text { and } \\
\text { (Group } 3 \text { or Group 4) }\end{array}$ & 573 & 21 \\
\hline
\end{tabular}

Limits: Humans, Journal Article, English, Publication Date from 1990/01/01 to $2011 / 12 / 31$. 
primary care setting; study publication dates between January 1990 and December 2011, quantitative data and at least 100 participants. We used a sample size eligibility requirement to ensure stable estimates of cancer prevention and screening as has been done [22,23]. Only 4 studies of more than 500 studies were excluded based solely on sample size. Reviews, editorials, letters, and essays were also excluded. Articles were initially reviewed by one author and any further decisions were discussed by all authors to determine if the study met all the eligibility criteria.

Ten studies met all of our eligibility criteria [24-33]. Because electronic searches may not identify all relevant studies [34], reference lists of the selected studies and published reviews of APRN/PAs and cancer screening or prevention were reviewed to identify other eligible studies. Five additional studies were identified in this manner [35-39]. A total of 15 studies are included in this paper.

\section{Data abstraction}

Data were abstracted from each paper using a standardized format in an excel spreadsheet. Study characteristics included: type of cancer screening test (Papanicolaou/ Pap test, mammogram and/or any colorectal cancer screening test, including fecal occult blood test (FOBT), flexible sigmoidoscopy, or colonoscopy) or prevention recommendations (smoking cessation, diet and/or physical activity), geographic setting of sample (national, state, local), study design (cross-sectional, intervention and retrospective cohort), study size, delivery setting (single institution, network of institutions and multiple nonnetwork institutions) and year of publication. Type of $A P R N / P A$ included NPs, CNMs, and PAs and was not a mutually exclusive category because some studies combined multiple types of APRN/PAs. Due to this and the limited number of studies, we reported on APRN/PAs as a combined unit unless the studies only focused on type of provider. The comparison group was recorded in three categories: physicians, other provider, and no comparison group. Where possible, comparisons were made between physicians and APRN/PAs. The patient and provider characteristics measured were age, gender, and race/ethnicity. The types of patient insurance coverage were also abstracted when reported. Cancer screening and prevention recommendations findings were abstracted as reported. Because some studies evaluated multiple screening tests and multiple types of prevention, these findings were abstracted and reported separately. The study cancer screening and prevention outcome measures were recorded in three categories: self-report, chart review, and biological samples. All study findings were abstracted as reported in the underlying study. This study fully conforms to the PRISMA guidelines for systematic reviews (http://www.prisma-statement.org).

\section{Results}

\section{Study characteristics}

A total of seven studies reported outcomes on screening for cervical, breast or colorectal cancer [24,26,28-31,39], while ten studies measured cancer prevention recommendations for smoking cessation, diet, and physical activity (Table 2) [25-27,31-33,35-38]. We did not identify any studies of HPV vaccination or of post-treatment survivorship care. Three studies reported outcomes on more than one type of cancer screening [24,26,39], and four studies reported on more than one type of cancer prevention recommendations [26,27,31,37]. Most studies were cross-sectional, showed results from within a single city or state, had relatively small sample sizes (less than 500) and reported on the behavior of NPs. Only three studies reported on interventions, two focusing on tobacco and one on Pap test and mammograms [32,38,39]. The majority of studies presented self-reported data from providers about their own practice or their perceptions of APRN/PAs practice [24,25,28,31,35,37], while only a few presented self-reported data from patients $[32,38]$. Few studies reported receipt of services or documented changes in behavior as part of chart reviews $[26,27,36,39]$. A small number reported any patient characteristics. The response rates for studies varied, with those that presented self-reported data from providers ranged from $30 \%$ to $72 \%$ [24,25,28-31,35,37]. Many of the studies did not specify whether the APRN/PAs provided or recommended cancer screening.

\section{Cancer screening}

\section{Cervical cancer screening}

Of the five studies evaluating Pap tests, most showed that APRN/PAs provide or recommend Pap tests to patients $(72 \%$ to $98 \%)$ and that physicians who currently work with APRN/PAs are amenable to APRN/PAs conducting Pap tests (Table 3) [24,26,29,31]. Physicians who practice in provider teams that include NPs and PAs are more supportive of NPs and PAs performing Pap tests that physicians who do not practice in provider teams that include NPs and PAs [29]. In addition, an intervention study compared NPs recommending and performing cervical cancer screening during routine visits to a provider reminder system. At follow-up there was a significant increase in the annual rate of women screened for cervical cancer by a NP at the intervention location (from $17.8 \%$ to $56.9 \%$ ), while the annual rate of screening by physicians at the control location improved less (from $11.8 \%$ to $18.2 \%$ ) during the study time period [39]. 
Table 2 Characteristics of studies of Advanced Practices Registered Nurses and Physician Assistants (APRN/PA) and cancer prevention and screening

\begin{tabular}{cccc}
\hline $\begin{array}{c}\text { Study } \\
\text { characteristics }\end{array}$ Study categories & $\begin{array}{c}\text { Number } \\
\text { of studies } \\
(\mathrm{N}=15)\end{array}$ & $\begin{array}{c}\text { Percentage } \\
\text { of studies }\end{array}$ \\
\hline
\end{tabular}

Type of cancer

prevention*

Diet/Physical activity
Smoking
Mammogram
Pap test
Colorectal cancer
screening

Study setting

National
State or regional
Local (City or Multiple
Counties)

Study design

$\begin{array}{ccc}\text { Intervention } & 3 & 20 \% \\ \text { Retrospective cohort } & 2 & 13 \% \\ \text { Cross sectional } & 10 & 67 \%\end{array}$

Study date of publication

$\begin{array}{ccc}<1995 & 2 & 13 \% \\ 1995-1999 & 3 & 20 \% \\ 2000-2004 & 4 & 27 \% \\ >=2005 & 6 & 40 \%\end{array}$

Type of APRN/PA provider

$\begin{array}{ccc}\begin{array}{c}\text { Advanced practice } \\ \text { nurse practitioner }\end{array} & 13 & 87 \% \\ \text { Certified nurse midwife } & 2 & 13 \% \\ \text { Physician Assistant } & 3 & 20 \% \\ & & \end{array}$

$\begin{array}{ccc}\text { Physicians } & 5 & 33 \% \\ \text { None } & 5 & 33 \% \\ \text { Other } & 5 & 33 \%\end{array}$

Sample size

$\begin{array}{ccc}100-499 & 8 & 53 \% \\ 500-999 & 1 & 7 \% \\ 1,000-4,999 & 5 & 33 \% \\ 5,000-19,999 & 0 & 0 \% \\ >20,000 & 1 & 7 \%\end{array}$

Healthcare delivery setting

Single institution or
clinic

Table 2 Characteristics of studies of Advanced Practices Registered Nurses and Physician Assistants (APRN/PA) and cancer prevention and screening (Continued)

\begin{tabular}{|c|c|c|c|}
\hline & $\begin{array}{c}\text { Network of institutions } \\
\text { or clinics }\end{array}$ & 3 & $20 \%$ \\
\hline & $\begin{array}{l}\text { Multiple institutions } \\
\text { (Not a Network) }\end{array}$ & 10 & $67 \%$ \\
\hline \multicolumn{4}{|l|}{ Outcome measure } \\
\hline & Chart review & 3 & $20 \%$ \\
\hline & $\begin{array}{l}\text { Self-Report by } \\
\text { physicians }\end{array}$ & 4 & $27 \%$ \\
\hline & $\begin{array}{c}\text { Self-Report by APRN/PA } \\
\text { providers }\end{array}$ & 6 & $47 \%$ \\
\hline & Self-Report by patients & 2 & $13 \%$ \\
\hline \multirow{2}{*}{\multicolumn{4}{|c|}{$\begin{array}{l}\text { Patient characteristics } \\
\text { Insurance types* }\end{array}$}} \\
\hline & & & \\
\hline & Any medicare & 2 & $13 \%$ \\
\hline & Any medicaid & 5 & $33 \%$ \\
\hline & Private & 6 & $40 \%$ \\
\hline & Not reported & 8 & $60 \%$ \\
\hline
\end{tabular}

\section{Breast cancer screening}

Of the three studies that studied breast cancer, two showed that a majority of patients who see NPs receive mammograms (69\% to $91 \%$ ) and that NPs recommend a similar amount of mammograms as physicians (Table 3) $[24,26]$. In the same NP intervention study mentioned previously for cervical cancer screening, the annual rate of mammography screening increased more among women seen at the NP screening recommendation site $(18.3 \%$ to $40.0 \%)$ than at the cancer screening program using a provider reminder checklist on charts and referrals (18.0\% at both time points) [39].

\section{Colorectal cancer screening}

Findings about APRN/PAs involvement in colorectal cancer screening are mixed and vary based on the screening modalities evaluated (Table 3). Of the four colorectal cancer screening studies, three showed a range of reported colorectal cancer screening provided or recommended by APRN/PAs (19\% to 95\%) [24,26,30]. This large variation in reported colorectal cancer screening is partially determined by the variation in reporting amongst the studies. The lowest percentage is based on chart review of an unspecified type of colorectal cancer screening among patients aged 50 and above [26] while the highest percentage is a self-reported survey answer from providers on how often they recommend FOBT to any patient (age not specified) [30]. We also found substantial variation in reporting on colorectal cancer screening modalities, with some studies reporting specific modalities [24] and others reporting whether an 
Table 3 Studies of Advanced Practices Registered Nurses and Physician Assistants (APRN/PA) and breast, cervical and colorectal cancer screening

\begin{tabular}{|c|c|c|c|c|c|c|}
\hline Study & Sample size & Outcome measure & Setting and study design & Pap findings & Mammogram findings & $\begin{array}{l}\text { Colorectal cancer screening } \\
\text { findings }\end{array}$ \\
\hline \multirow[t]{13}{*}{ Menees et al., [24] } & \multirow[t]{2}{*}{$\begin{array}{l}\text { Total providers: } 336 \\
\text { OB/GYNS: } 182\end{array}$} & \multirow[t]{2}{*}{$\begin{array}{l}\text { Self-Report of MDs } \\
\text { and NPs }\end{array}$} & $\begin{array}{l}\text { National survey of OB/GYNs } \\
\text { and NPs }\end{array}$ & $\begin{array}{l}\text { Pap test routinely } \\
\text { provided: }\end{array}$ & $\begin{array}{l}\text { Mammography routinely } \\
\text { recommended: }\end{array}$ & $\begin{array}{l}\text { CRC screening routinely } \\
\text { recommended: }\end{array}$ \\
\hline & & & Cross sectional Survey & NPs: $94.8 \%$ & NPs: $90.9 \%$ & NPs: $61.7 \%$ \\
\hline & \multirow[t]{11}{*}{ NPS: 154} & & & OB/GYNs: $97.8 \%$ & OB/GYNs: 98.9\% & OB/GYNs: $87.2 \%$ \\
\hline & & & & $P<0.01$ & $P<0.01$ & $P<0.01$ \\
\hline & & & & Unadjusted & Unadjusted & $\begin{array}{l}\text { Most common CRC screening } \\
\text { recommended by either } \\
\text { provider: }\end{array}$ \\
\hline & & & & & & FOBT: $76.2 \%$ \\
\hline & & & & & & Colonoscopy: $28.3 \%$ \\
\hline & & & & & & P-value not reported \\
\hline & & & & & & Ordered colonoscopy: \\
\hline & & & & & & NPs: $19.8 \%$ \\
\hline & & & & & & OB/GYNs: $37 \%$ \\
\hline & & & & & & $P<0.005$ \\
\hline & & & & & & All measures unadjusted \\
\hline \multirow[t]{5}{*}{ Hopkins et al., [26] } & Total patients: 1339 & Chart review & Chart review in private practice & Receipt of Pap test: & $\begin{array}{l}\text { Receipt of mammogram: } \\
\text { (Aged } 40+\text { ) }\end{array}$ & $\begin{array}{l}\text { Patient receipt of colorectal } \\
\text { screening: (Ages } 50+\text { ) }\end{array}$ \\
\hline & \multirow[t]{2}{*}{ PHCC NP patients: 755} & & \multirow{2}{*}{$\begin{array}{l}\text { and primary care health centers } \\
\text { in New York City }\end{array}$} & PHCC NPs: $71.5 \%$ & PHCC NPs: $69 \%$ & PHCC NPs: $19.1 \%$ \\
\hline & & & & PHCC MDs: $53.8 \%$ & PHCC MDs: $64.2 \%$ & PHCC MDs: $45.7 \%$ \\
\hline & MD patients: 441 & & \multirow[t]{2}{*}{ Retrospective cohort } & $P<0.001$ & $P=0.240$ & $P<0.001$ \\
\hline & PP NP patients: 143 & & & Unadjusted & Unadjusted & Unadjusted \\
\hline \multirow[t]{8}{*}{ Sansbury et al., [28] } & Total providers: 1900 & $\begin{array}{l}\text { Self-Report of MDs } \\
\text { about APRN/PAs }\end{array}$ & National survey of MDs & NA & NA & $\begin{array}{l}\text { Work with NP/PA to provide } \\
\text { FOBT: }\end{array}$ \\
\hline & PC MDs: 1235 & & Cross sectional survey & & & MDs report working with a NP \\
\hline & \multirow[t]{6}{*}{ NPC MDs: 665} & & & & & or PA to provide FOBT: $23.8 \%$ \\
\hline & & & & & & $\begin{array}{l}\text { Of the } 24 \% \text { of physicians who } \\
\text { work with NP/PA for FOBT, } \\
\text { they reported frequency of } \\
\text { supervising a NP or PA for } \\
\text { FOBT: }\end{array}$ \\
\hline & & & & & & Supervised a NP: 75\% \\
\hline & & & & & & Supervised a PA: 25\% \\
\hline & & & & & & $\begin{array}{l}\text { P-value not reported for all } \\
\text { measures }\end{array}$ \\
\hline & & & & & & All measures unadjusted \\
\hline
\end{tabular}


Table 3 Studies of Advanced Practices Registered Nurses and Physician Assistants (APRN/PA) and breast, cervical and colorectal cancer screening (Continued)

\begin{tabular}{|c|c|c|c|c|c|c|}
\hline \multirow[t]{15}{*}{ Oliveria et al., [29] } & Total providers: 1363 & $\begin{array}{l}\text { Self-Report of MDs } \\
\text { about APRN/PAs }\end{array}$ & National survey of MDs & $\begin{array}{l}\text { MDs amenable to } \\
\text { NP/PA screening: }\end{array}$ & NA & NA \\
\hline & \multirow[t]{14}{*}{ MDs: 1363} & & \multirow[t]{14}{*}{ Cross sectional survey } & Team Practice^: 89.6\% & & \\
\hline & & & & $\begin{array}{l}\text { Non-team Practice } \wedge \text { : } \\
59.9 \%\end{array}$ & & \\
\hline & & & & $\begin{array}{l}\text { Team vs Non-team of } \\
\text { amenable MDs: }\end{array}$ & & \\
\hline & & & & $\begin{array}{l}\mathrm{OR}=8.11(95 \% \mathrm{Cl}: \\
5.80-11.35)\end{array}$ & & \\
\hline & & & & $P=0.001$ & & \\
\hline & & & & $\begin{array}{l}\text { MDs reporting NP/PA } \\
\text { screening: }\end{array}$ & & \\
\hline & & & & $\begin{array}{l}\text { All MDs reporting } \\
\text { frequency of NPs } \\
\text { or PAs performing } \\
\text { Pap tests: }\end{array}$ & & \\
\hline & & & & NPs: $33.5 \%$ & & \\
\hline & & & & PAs: $23.2 \%$ & & \\
\hline & & & & $\begin{array}{l}\text { Team practice MDs } \\
\text { reporting frequency } \\
\text { of NP/PA performing } \\
\text { Pap tests: }\end{array}$ & & \\
\hline & & & & NPs: $89.3 \%$ & & \\
\hline & & & & PAs: $82.7 \%$ & & \\
\hline & & & & $\begin{array}{l}\text { P-value not reported } \\
\text { for all other measures }\end{array}$ & & \\
\hline & & & & All measures unadjusted & & \\
\hline \multirow[t]{9}{*}{ Shaheen et al., [30] } & Total providers: 1784 & \multirow[t]{9}{*}{ Self-Report of APRN/PAs } & $\begin{array}{l}\text { Survey of NPs and PAs in } \\
\text { North Carolina }\end{array}$ & NA & NA & $\begin{array}{l}\text { NP/PA who recommend/ } \\
\text { perform FOBT: }\end{array}$ \\
\hline & Total NPs: 526 & & \multirow[t]{8}{*}{ Cross sectional survey } & & & Primary Care PA: 94.6\% \\
\hline & Total PAs: 640 & & & & & Primary Care NP: 92.1\% \\
\hline & PC PAs: 322 & & & & & NP/PA who recommend/perform \\
\hline & \multirow[t]{5}{*}{ PC NPs: 270} & & & & & flexible sigmoidoscopy: \\
\hline & & & & & & Primary Care PA: 76.1\% \\
\hline & & & & & & Primary Care NP: 69.2\% \\
\hline & & & & & & P-value not reported \\
\hline & & & & & & Unadjusted \\
\hline
\end{tabular}


Table 3 Studies of Advanced Practices Registered Nurses and Physician Assistants (APRN/PA) and breast, cervical and colorectal cancer screening (Continued)

\begin{tabular}{|c|c|c|c|c|c|c|}
\hline \multirow[t]{4}{*}{ 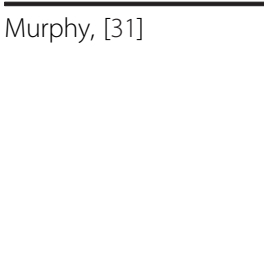 } & Total providers: 346 & \multirow[t]{4}{*}{ Self-Reportof CNMs } & National survey of CNMs & \multirow{2}{*}{$\begin{array}{l}98 \% \text { of CNMs report } \\
\text { they routinely provide } \\
\text { pap tests to } 81-100 \% \\
\text { of their gynecologic } \\
\text { patients }\end{array}$} & \multirow[t]{4}{*}{$\mathrm{NA}$} & \multirow[t]{4}{*}{ NA } \\
\hline & \multirow[t]{3}{*}{ CNMs: 346} & & \multirow[t]{3}{*}{ Cross sectional survey } & & & \\
\hline & & & & P-value not reported & & \\
\hline & & & & Unadjusted & & \\
\hline \multirow[t]{10}{*}{ Mandelblatt et al., [39] } & \multirow{3}{*}{$\begin{array}{l}\text { Total patients: } 319 \\
\text { Intervention: } 160 \\
\text { Control: } 159\end{array}$} & \multirow[t]{10}{*}{ Chart review } & \multirow{3}{*}{$\begin{array}{l}\text { Two New York City study } \\
\text { hospitals with NP led } \\
\text { intervention and usual } \\
\text { care control }\end{array}$} & \multirow{2}{*}{$\begin{array}{l}\text { Receipt of Pap test in } \\
\text { intervention group: }\end{array}$} & \multirow{2}{*}{$\begin{array}{l}\text { Receipt of mammography } \\
\text { in intervention group: }\end{array}$} & \multirow[t]{3}{*}{ NA } \\
\hline & & & & & & \\
\hline & & & & Baseline: 17.8\% & Baseline: 18.3\% & \\
\hline & \multirow{7}{*}{$\begin{array}{l}\text { Total providers: Not } \\
\text { Reported }\end{array}$} & & \multirow[t]{7}{*}{ Intervention } & Post: $56.9 \%$ & Post: $40 \%$ & \\
\hline & & & & $P<0.01$ & $P<0.01$ & \\
\hline & & & & $\begin{array}{l}\text { Receipt of Pap test in } \\
\text { control group: }\end{array}$ & $\begin{array}{l}\text { Receipt of mammography } \\
\text { in control group: }\end{array}$ & \\
\hline & & & & Baseline: 11.8\% & Baseline: $18.1 \%$ & \\
\hline & & & & Post: $18.2 \%$ & Post: $18.2 \%$ & \\
\hline & & & & P-value not reported & P-value not reported & \\
\hline & & & & All measures unadjusted & All measures unadjusted & \\
\hline
\end{tabular}

$\wedge=($ MDs who work with NPs or PAs)

$\wedge \wedge=$ (MDs who do not work with NPs or PAs).

$\mathrm{NA}=$ Not Applicable.

$N P C=$ Non-Primary Care.

$\mathrm{NPC}=$ Non-Primary
$\mathrm{NP} / \mathrm{PA}=\mathrm{NP}$ or PA.

$\mathrm{PHCC}=$ Primary Health Care Center.

$P C=$ Primary Care

$\mathrm{PC}=$ Primary Care.
$\mathrm{PP}=$ Private practice

${ }^{*}=\mathrm{A}$ higher number means the provider does the behavior more frequently.

$\mathrm{Cl}=$ Confidence Interval. 
unspecified type of colorectal cancer screening was offered [26]. In addition, two of the studies showed physicians reporting more colorectal cancer screening than APRN/PAs [24,26]. Only $24 \%$ of practicing primary care physicians reported working with APRN/PAs to provide FOBT in a nationally representative survey [28].

\section{Recommendations for cancer prevention Smoking cessation recommendations}

Both physicians and APRN/PAs report frequently providing smoking cessation recommendations (Table 4). APRN/PAs self-reported a range of assessment of tobacco use and smoking cessation recommendations to patients $(7 \%$ to $95 \%)$ in eight studies $[25,26,31,32,36]$. Of the nine studies that measured tobacco related outcomes, three showed that patients are more likely to receive recommendations for smoking cessation during visits with NPs than during visits without NPs (associations not always statistically significant) while another study showed MDs feel that they are more adequately trained to give smoking cessation counseling than NPs $[27,32,37,38]$. One smoking cessation intervention of NPs at a prenatal clinic visit compared to a usual care control prenatal clinic visit reported significantly increased abstinence among cigarette smokers at followup (19\% vs. 0\%) [38].

\section{Diet and physical activity recommendations}

The four studies that evaluated diet also evaluated physical activity, while one study only evaluated physical activity counseling (Table 4). These studies showed that while APRN/PAs do not frequently provide recommendations on diet and physical activity ( $12 \%$ to $52 \%)$, they do provide more recommendations related to diet and physical activity than their physician counterparts (3\% to 15\%) $[26,27,31,37]$.

\section{Discussion}

In this paper, we reviewed the recent literature on the participation and roles of APRN/PAs in the delivery of cancer prevention and screening recommendations in US primary care settings. In the descriptive or intervention research we identified, only 15 studies during a 21 year period, APRN/PAs are involved in recommending cancer screening and prevention. The limited research is somewhat surprising, because a team approach, including physicians and APRN/PAs, has long been recommended for improving healthcare [18-21,40]. After receiving the appropriate training, APRN/PAs expect to provide or recommend Pap tests, mammograms and FOBT, while studies only reported on physicians working concurrently with APRN/PAs to screen for cervical cancer [29] and colorectal cancer [28]. With the enactment of the Affordable Care Act, millions of previously uninsured or underinsured will gain access to healthcare. A better understanding of the potential roles of APRN/ PAs in meeting this demand for cancer prevention and screening is critical.

The integration of more APRN/PAs into primary care can affect cancer screening and recommendations in several different ways. This integration has the potential to increase the overall percentage of the population ever receiving specific cancer prevention and screening recommendations, as was shown in an intervention study included in this review [39]. For example, colorectal cancer screening uptake in the US is substantially lower than for breast or cervical cancer screening [41]. The US Preventive Services Task Force (USPSTF) recommends any of three different tests for colorectal cancer (i.e., FOBT, flexible sigmoidoscopy, colonoscopy) [4]. These tests have different screening intervals, involvement of specialists, levels of invasiveness and other characteristics [4], potentially requiring detailed discussion to allow patients to make informed decisions about screening. Currently, less than $25 \%$ of physicians report actually working with APRN/PAs to provide colorectal cancer screening [28]. However, one challenge with moving forward with teambased health care is that physicians do not always want to work with nurse practitioners [42].

In a time constrained primary care setting, APRN/PAs might play a critical role in improving discussion about options and ultimately improving uptake of colorectal cancer screening. Alternatively, research featuring APRN/ PAs might focus on improving all aspects of cancer control among specific populations, such as those previously uninsured or with key risk factors. Lack of health insurance and lack of prior screening has been consistently associated with late stage of disease at diagnosis for breast, cervical, and colorectal cancer [43-45]. Tobacco use and obesity are associated with many chronic diseases [46] and the role of APRN/PAs in encouraging healthy behaviors could improve a variety of health outcomes of the US population. Future research is needed that investigates that relationship between a visit with an APRN/PA and other primary care provider types within team-based primary care that oversamples racial and ethnic minorities and lower socioeconomic status populations.

We identified a number of methodological and reporting limitations in the studies included in this review related to study design and reporting of outcome measures and sample characteristics. Most of the studies were crosssectional and did not assess cancer prevention or screening outcomes longitudinally. Surprisingly, only three studies reported results of interventions, therefore not allowing for a quantitative analysis of using APRN/PAs for cancer screening or prevention recommendations [32,38,39]. Few reported the type of APRN or PA provider separately, included comparison groups, or were based on well-described 
Table 4 Studies of Advanced Practices Registered Nurses and Physician Assistants (APRN/PA) and diet, physical activity, and smoking cessation recommendations

\begin{tabular}{|c|c|c|c|c|c|c|}
\hline Study & Sample size & Outcome measure & Setting & Findings for diet & Findings for physical activity & Findings for smoking cessation \\
\hline \multirow{9}{*}{$\begin{array}{l}\text { Tompkins } \\
\text { et al., [33] }\end{array}$} & Total providers: 398 & \multirow[t]{9}{*}{ Self-report of NPs } & \multirow{2}{*}{$\begin{array}{l}\text { Survey of NPs at } \\
\text { Pacific Northwest } \\
\text { Annual National } \\
\text { Conference }\end{array}$} & \multirow[t]{9}{*}{ NA } & \multirow{2}{*}{$\begin{array}{l}\text { Physical activity counseling of } \\
\text { appropriate patient in past } \\
\text { week: }\end{array}$} & \multirow[t]{9}{*}{ NA } \\
\hline & NPs: 398 & & & & & \\
\hline & & & \multirow[t]{7}{*}{ Cross sectional survey } & & $\begin{array}{l}25 \% \text { of NPs reported counseling } \\
50 \% \text { of appropriate patients }\end{array}$ & \\
\hline & & & & & $\begin{array}{l}37.75 \% \text { of NPs reported counseling } \\
75 \% \text { of appropriate patients }\end{array}$ & \\
\hline & & & & & $\begin{array}{l}14.8 \% \text { of NPs reported counseling } \\
100 \% \text { of appropriate patients }\end{array}$ & \\
\hline & & & & & $\begin{array}{l}\text { Selected factors that facilitate } \\
\text { physical activity counseling with } \\
\text { patients: }\end{array}$ & \\
\hline & & & & & $\begin{array}{l}69.2 \% \text { of NPs reported length of } \\
\text { patient visit }\end{array}$ & \\
\hline & & & & & $\begin{array}{l}55.4 \% \text { of NPs reported part of } \\
\text { preventative health visit }\end{array}$ & \\
\hline & & & & & P-value not reported & \\
\hline \multirow{15}{*}{$\begin{array}{l}\text { Patton et al., } \\
\text { [25] }\end{array}$} & Total providers: 1802 & \multirow{15}{*}{$\begin{array}{l}\text { Self-report of MDs } \\
\text { and NPs }\end{array}$} & \multirow{3}{*}{$\begin{array}{l}\text { Surveys of health } \\
\text { professionals in } \\
\text { North Carolina }\end{array}$} & \multirow[t]{15}{*}{ NA } & \multirow[t]{15}{*}{ NA } & NPs report that they assess: \\
\hline & Family physicians: 273 & & & & & Patient's past tobacco use: $95.1 \%$ \\
\hline & NPs: 294 & & & & & Patient's present tobacco use: $\mathbf{9 7 . 9 \%}$ \\
\hline & Dentists: 584 & & \multirow[t]{12}{*}{ Cross sectional Survey } & & & Type and amount of tobacco: $92.3 \%$ \\
\hline & Hygienists: 651 & & & & & P-value not reported \\
\hline & & & & & & Family MDs report that they assess: \\
\hline & & & & & & Patient's past tobacco use: $98.5 \%$ \\
\hline & & & & & & Patient's present tobacco use: $100 \%$ \\
\hline & & & & & & Type and amount of tobacco: $95.5 \%$ \\
\hline & & & & & & P-value not reported \\
\hline & & & & & & $\begin{array}{l}\text { Adequately trained for smoking } \\
\text { cessation }\end{array}$ \\
\hline & & & & & & NPs: $71.4 \%$ \\
\hline & & & & & & Family MD: 93.5\% \\
\hline & & & & & & P-value not reported \\
\hline & & & & & & $\begin{array}{l}\text { Physicians are significantly more } \\
\text { likely to feel adequately trained to } \\
\text { provide tobacco cessation compared } \\
\text { to NPs }\end{array}$ \\
\hline
\end{tabular}


Table 4 Studies of Advanced Practices Registered Nurses and Physician Assistants (APRN/PA) and diet, physical activity, and smoking cessation recommendations (Continued)

\begin{tabular}{|c|c|c|c|c|c|c|}
\hline & & & & & & $\mathrm{OR}=5.3(3.2-8.6)$ \\
\hline & & & & & & P-value $<.0001$ \\
\hline & & & & & & All measures unadjusted \\
\hline \multirow[t]{6}{*}{$\begin{array}{l}\text { Price et al., } \\
\text { [35] }\end{array}$} & Total providers: 194 & \multirow[t]{6}{*}{ Self-report of CNMs } & $\begin{array}{l}\text { Survey of CNMs } \\
\text { in Ohio }\end{array}$ & \multirow[t]{6}{*}{ NA } & \multirow[t]{6}{*}{ NA } & $\begin{array}{l}\text { CNMs reported that they } \\
\text { always/usually: }\end{array}$ \\
\hline & CNMs: 194 & & \multirow[t]{5}{*}{ Cross sectional survey } & & & $\begin{array}{l}\text { Document cigarette smoking use } \\
\text { status at each visit: } 73 \%\end{array}$ \\
\hline & \multirow[t]{4}{*}{$\begin{array}{l}\text { All patients pregnant } \\
\text { women }\end{array}$} & & & & & $\begin{array}{l}\text { Assess whether the patient is willing } \\
\text { to make a quit attempt within the } \\
\text { next } 30 \text { days: } 66 \%\end{array}$ \\
\hline & & & & & & $\begin{array}{l}\text { Use counseling to help patients } \\
\text { willing to make a quit attempt: } 48 \%\end{array}$ \\
\hline & & & & & & P-value not reported for all measures \\
\hline & & & & & & All measures unadjusted \\
\hline \multirow{10}{*}{$\begin{array}{l}\text { Running } \\
\text { et al., [36] }\end{array}$} & Total patients: 400 & \multirow[t]{10}{*}{ Chart review } & \multirow{3}{*}{$\begin{array}{l}\text { Chart review of } \\
\text { urgent care setting } \\
\text { in } \mathrm{HMO} \text { in the } \\
\text { Southwest }\end{array}$} & \multirow[t]{10}{*}{ NA } & \multirow[t]{10}{*}{ NA } & Smoking cessation addressed \\
\hline & NP patients: 200 & & & & & $\begin{array}{l}\text { among non-pharmacological } \\
\text { interventions for sinusitis: }\end{array}$ \\
\hline & \multirow[t]{8}{*}{ Physician patients: 200} & & & & & \\
\hline & & & \multirow[t]{7}{*}{ Retrospective cohort } & & & NPs: 49\% \\
\hline & & & & & & MDs: $31 \%$ \\
\hline & & & & & & $\begin{array}{l}\text { Number of times smoking cessation } \\
\text { is addressed for subjects in all } \\
\text { categories }\end{array}$ \\
\hline & & & & & & NPs: .97 \\
\hline & & & & & & MDs: 1.95 \\
\hline & & & & & & P-value $=.309$ \\
\hline & & & & & & Unadjusted \\
\hline \multirow{6}{*}{$\begin{array}{l}\text { Hopkins } \\
\text { et al., [26] }\end{array}$} & Total Patients: 1339 & \multirow[t]{6}{*}{ Chart review } & \multirow{4}{*}{$\begin{array}{l}\text { Chart review in private } \\
\text { practice and primary } \\
\text { care health centers in } \\
\text { NY City }\end{array}$} & Receipt of assessment and & Receipt of assessment and & Receipt of assessment and \\
\hline & \multirow{2}{*}{$\begin{array}{l}\text { Primary health care center } \\
\text { (PHCC) NP patients: } 755\end{array}$} & & & $\begin{array}{l}\text { counseling on nutrition } \\
\text { and diet: }\end{array}$ & counseling on physical activity: & counseling on tobacco use: \\
\hline & & & & PHCC NPs: $41.4 \%$ & PHCC NPs: $15.8 \%$ & PHCC NPs: $79.2 \%$ \\
\hline & MD patients: 441 & & & PHCC MDs: $14.7 \%$ & PHCC MDs: $2.5 \%$ & PHCC MDs: $87.8 \%$ \\
\hline & \multirow{2}{*}{$\begin{array}{l}\text { Private practice NP patients: } \\
143\end{array}$} & & \multirow[t]{2}{*}{ Retrospective cohort } & P-value $=0.000$ & P-value $=0.000$ & P-value $=0.000$ \\
\hline & & & & Unadjusted & Unadjusted & Unadjusted \\
\hline
\end{tabular}


Table 4 Studies of Advanced Practices Registered Nurses and Physician Assistants (APRN/PA) and diet, physical activity, and smoking cessation recommendations (Continued)

\begin{tabular}{|c|c|c|c|c|c|c|}
\hline \multirow[t]{8}{*}{ Lin et al., [27] } & $\begin{array}{l}\text { Total hospital outpatient } \\
\text { department visits: 90,476 }\end{array}$ & \multirow[t]{8}{*}{ Chart review } & $\begin{array}{l}\text { National survey of } \\
\text { hospital ambulatory } \\
\text { settings (NAMCS) }\end{array}$ & $\begin{array}{l}\text { Received diet counseling at an } \\
\text { OPD visit with a NP compared } \\
\text { to one without a NP }\end{array}$ & $\begin{array}{l}\text { Received physical activity counseling } \\
\text { at an OPD visit with a NP compared } \\
\text { to one without a NP }\end{array}$ & $\begin{array}{l}\text { Received tobacco use counseling at } \\
\text { an OPD visit with a NP compared to } \\
\text { one without a NP }\end{array}$ \\
\hline & Visits with NP: 6,062 & & Cross sectional survey & $32.6 \%$ vs. $22.9 \%$ & $14.5 \%$ vs. $9.3 \%$ & $6.7 \%$ vs. $4.3 \%$ \\
\hline & Visits without NP: 84,416 & & \multirow{6}{*}{$\begin{array}{l}\text { Odds ratio adjusted for } \\
\text { patient age, sex, clinic } \\
\text { type, metropolitan status, } \\
\text { geographic region of } \\
\text { hospital, and number of } \\
\text { providers seen. }\end{array}$} & $\begin{array}{l}\text { Non-illness patients: } 1.7 \text { OR } \\
\text { ( } 95 \% \text { Cl OR: } 1.2-2.5)\end{array}$ & $\begin{array}{l}\text { Non-illness patients: } 1.8 \text { OR } \\
\text { (95\% CI OR: 1.2-2.8) }\end{array}$ & $\begin{array}{l}\text { Non-illness patients: } 1.7 \text { OR ( } 95 \% \text { Cl } \\
\text { OR: 1.2-2.5) }\end{array}$ \\
\hline & & & & $P$ - value $=0.004$ & $P$ - value $=0.007$ & $P$ - value $=0.004$ \\
\hline & & & & $\begin{array}{l}\text { OPD visits for patients with chronic } \\
\text { problems with a NP compared to } \\
\text { one without a NP: }\end{array}$ & $\begin{array}{l}\text { OPD visits for patients with } \\
\text { chronic problems with a NP } \\
\text { compared to one without a NP: }\end{array}$ & $\begin{array}{l}\text { OPD visits for patients with chronic } \\
\text { problems with a NP compared to } \\
\text { one without a NP: }\end{array}$ \\
\hline & & & & $32.3 \%$ vs. $17.1 \%$ & $20.2 \%$ vs. $8.9 \%$ & $4.7 \%$ vs. $2.9 \%$ \\
\hline & & & & 2.5 OR (95\% Cl OR: 1.6-3.8) & 2.8 OR (95\% Cl OR: 1.6-5.1) & 1.8 OR (95\% Cl OR: 1.1-3.0) \\
\hline & & & & P-value $=0.001$ & P-value $=0.007$ & P-value $=0.01$ \\
\hline \multirow[t]{5}{*}{$\begin{array}{l}\text { Moody } \\
\text { et al., [37] }\end{array}$} & Total Providers: 44 & Self-report of & $\begin{array}{l}\text { Survey of NPs in } \\
\text { Tennessee }\end{array}$ & Provider report nutrition counseling: & $\begin{array}{l}\text { Provider report physical activity } \\
\text { counseling: }\end{array}$ & $\begin{array}{l}\text { Provider report smoking cessation } \\
\text { counseling: }\end{array}$ \\
\hline & NPs: 44 & \multirow[t]{4}{*}{ NPs } & \multirow[t]{4}{*}{ Cross sectional survey } & NPs: $19 \%$ & NPs: $12 \%$ & NPs: $7 \%$ \\
\hline & \multirow[t]{3}{*}{ Total patients: 680} & & & MDs: $15 \%$ & MDs: $7 \%$ & MDs: $2.5 \%$ \\
\hline & & & & P-value not reported & P-value not reported & P-value not reported \\
\hline & & & & Unadjusted & Unadjusted & Unadjusted \\
\hline \multirow[t]{12}{*}{$\begin{array}{l}\text { Gebauer } \\
\text { et al., [38] }\end{array}$} & Total patients: 178 & \multirow{12}{*}{$\begin{array}{l}\text { Self-report of patients } \\
\text { and Salivary } \\
\text { Cotinine Sample }\end{array}$} & \multirow{2}{*}{$\begin{array}{l}\text { Follow up survey at } \\
\text { outpatient obstetric } \\
\text { clinic - state not } \\
\text { specified }\end{array}$} & \multirow[t]{2}{*}{ NA } & \multirow[t]{12}{*}{ NA } & $\begin{array}{l}\text { Smoking rate/day at follow-up: } \\
\text { Mean (SD) }\end{array}$ \\
\hline & Control patients: 94 & & & & & Control: 13.7 (14.1) \\
\hline & Intervention patients: 84 & & \multirow[t]{10}{*}{ Intervention } & & & Intervention: 7.8 (7.3) \\
\hline & \multirow{9}{*}{$\begin{array}{l}\text { All patients pregnant women } \\
\text { who report smoking and } \\
\text { intervention includes being } \\
\text { seen by an advance practice NP }\end{array}$} & & & & & $P=.008$ \\
\hline & & & & & & Unadjusted \\
\hline & & & & & & Smoked any amount in past 7 days: \\
\hline & & & & & & Control Baseline: 94 participants \\
\hline & & & & & & Control Follow up: 94 participants \\
\hline & & & & & & Intervention Baseline: 83 participants \\
\hline & & & & & & $\begin{array}{l}\text { Intervention Follow up: } 70 \\
\text { participants }\end{array}$ \\
\hline & & & & & & $\begin{array}{l}\text { Difference between groups }=15.5 \% \\
\text { P-value }<0.001\end{array}$ \\
\hline & & & & & & Unadjusted \\
\hline
\end{tabular}


Table 4 Studies of Advanced Practices Registered Nurses and Physician Assistants (APRN/PA) and diet, physical activity, and smoking cessation recommendations (Continued)

\begin{tabular}{|c|c|c|c|c|c|c|}
\hline \multirow[t]{4}{*}{$\begin{array}{l}\text { Murphy, } \\
{[31]}\end{array}$} & Total providers: 346 & Self-report of CNMs & $\begin{array}{l}\text { National survey of } \\
\text { CNMs }\end{array}$ & $\begin{array}{l}\text { Nutritional counseling of gynecologic } \\
\text { patients }\end{array}$ & $\begin{array}{l}\text { Physical activity counseling of } \\
\text { gynecologic patients }\end{array}$ & $\begin{array}{l}\text { Smoking cessation counseling of } \\
\text { gynecologic patients }\end{array}$ \\
\hline & CNMs: 346 & & Cross sectional survey & $\begin{array}{l}52 \% \text { of CNMs report counseling } \\
81-100 \% \text { of their patients }\end{array}$ & $\begin{array}{l}46 \% \text { of CNMs report counseling } \\
81-100 \% \text { of their patients }\end{array}$ & $\begin{array}{l}72 \% \text { of CNMs report counseling } \\
81-100 \% \text { of their patients }\end{array}$ \\
\hline & & & & P-value not reported & P-value not reported & P-value not reported \\
\hline & & & & Unadjusted & Unadjusted & Unadjusted \\
\hline \multirow[t]{9}{*}{$\begin{array}{l}\text { Zahnd et al., } \\
\text { [32] }\end{array}$} & Total patients: 1217 & $\begin{array}{l}\text { Self-report of } \\
\text { patients }\end{array}$ & \multirow{4}{*}{$\begin{array}{l}\text { Survey of patients } \\
\text { from Four Kaiser } \\
\text { Permanente Medical } \\
\text { Centers in San } \\
\text { Francisco Bay Area }\end{array}$} & \multirow[t]{4}{*}{ NA } & \multirow[t]{4}{*}{ NA } & $\begin{array}{l}\text { Patients report discussing smoking } \\
\text { cessation: }\end{array}$ \\
\hline & NP patients: 269 & & & & & NP Patients: 64\% \\
\hline & \multirow[t]{2}{*}{ Physician patients: 948} & & & & & MD Patients: 50\% \\
\hline & & & & & & P-value $<0.001$ \\
\hline & Total providers: 52 & & Intervention & & & Unadjusted \\
\hline & Physicians: 40 & & & & & $\begin{array}{l}\text { Independent predictors of } \\
\text { counseling about smoking: }\end{array}$ \\
\hline & \multirow[t]{3}{*}{ NPs: 12} & & & & & NP vs. Physician: OR 1.7 \\
\hline & & & & & & P-value $=.0006$ \\
\hline & & & & & & $\begin{array}{l}\text { Adjusted for differences in patient } \\
\text { characteristics }\end{array}$ \\
\hline $\begin{array}{l}\text { * }=\mathrm{A} \text { higher nun } \\
\mathrm{Cl}=\text { Confidence } \\
\mathrm{NA}=\text { Not Appli } \\
\mathrm{NPC}=\text { Non-Prir } \\
\text { NP/PA = NP or } \\
\mathrm{PHCC}=\text { Priman } \\
\mathrm{PC}=\text { Primary } \mathrm{C} \\
\mathrm{PP}=\text { Private pre }\end{array}$ & $\begin{array}{l}\text { aber means the provider do } \\
\text { Interval. } \\
\text { cable. } \\
\text { nary Care. } \\
\text { PA. } \\
\text { Health Care Center. } \\
\text { are. } \\
\text { actice. }\end{array}$ & navior more frequently. & & & & \\
\hline
\end{tabular}


samples (Tables 3 and 4) [24-28,36,38,39]. In addition, studies that did include comparison groups did not consistently report on statistical significance of comparisons. Inconsistencies in outcome measure reporting among these studies impacted our ability to compare guideline adherence and patient populations. Few studies evaluated whether screening recommendations were consistent with evidence-based guidelines for patient age at initiation or frequency $[24,26]$. This is particularly important because both overuse and underuse of screening can have adverse patient outcomes [47-49]. Most of the studies neglected to report patient demographics or key covariates, such as weight, body mass index, and comorbidities, hindering our ability to determine if either physicians or APRN/PAs are providing cancer screening based on guidelines.

Outcome measures were most commonly reported using either provider or patient self-reported data about recommendations and did not report on receipt of service or a documented change in behavior [24,25,30-33,35,37]. Even further removed from receipt of service, some studies reported what physicians perceived of APRN/PAs practice $[28,29]$. Self-reported and proxy-reported data may over or underestimate documented receipt of APRN/ PA provider services [50]. Further, primary care addresses multiple preventive services, but only about half of the studies included more than one aspect of cancer control and no studies address post-treatment survivorship care $[24,26,27,31,37,39]$. Future research should address these limitations and be conducted in longitudinal cohorts with comparison groups of well-described provider types, document patient receipt of screening or prevention recommendations, and assess multiple cancer control recommendations. Use of standardized measures, including for patient characteristics associated with guideline recommendations, evaluation of guideline adherence and longer term patient outcomes will also be important.

Despite using a large number of search terms to identify published studies, manually reviewing all abstracts and relevant reference lists, it is possible we missed some relevant studies. The studies we identified were fairly heterogeneous in terms of patient populations, geographic region, provider type, and type of a comparison group. Additionally, included studies used a variety of approaches to measure cancer screening and prevention, such as physician, non-physician provider and patient self-report, as well as chart review. As a result, our synthesis of findings was descriptive rather than quantitative. Findings are generalizable only to the primary care setting.

\section{Conclusion}

In summary, further documentation of the role of APRN/PAs in recommending and providing cancer prevention and screening services in US primary care teams is needed. Ensuring that future research measures cancer screening according to evidence-based USPSTF guidelines decreases variability among measures reporting and focuses on receipt of services. This will allow stakeholders to make more informed decisions on how best to utilize this growing workforce and provide cancer prevention and screening services to the US population.

\section{Competing interests}

The authors declare that they have no competing interests.

\section{Authors' contributions}

AS reviewed articles for initial eligibility, created tables and drafted manuscript. AS, DK and RY reviewed final articles for eligibility, provided study analysis and edited the manuscript. All authors read and approved the final manuscript.

\section{Acknowledgements}

We would like to acknowledge Ms. Echo Warner, MPH (Research Analyst at the Huntsman Cancer Institute) for her assistance on the literature review for this study.

\section{Author details}

${ }^{1}$ American Legacy Foundation, Washington, DC, USA. ${ }^{2}$ Division of Cancer Control and Population Sciences, National Cancer Institute, Bethesda, MD, USA. ${ }^{3}$ College of Nursing, University of Utah, Salt Lake City, UT. ${ }^{4}$ Cancer Control and Population Sciences, Huntsman Cancer Institute, Salt Lake City, UT.

Received: 16 August 2013 Accepted: 7 February 2014

Published: 12 February 2014

\section{References}

1. Addressing The Cancer Burden: At A Glance. http://www.cdc.gov/ chronicdisease/resources/publications/AAG/dcpc.htm.

2. Screening for Cervical Cancer. http://www.uspreventiveservicestaskforce. org/uspstf/uspscerv.htm.

3. Screening for Breast Cancer. http://www.uspreventiveservicestaskforce.org/ uspstf/uspsbrca.htm.

4. Screening for Colorectal Cancer. http://www.uspreventiveservicestaskforce. org/uspstf/uspscolo.htm.

5. Behavioral counseling to promote a healthful diet and physical sctivity for cardiovascular disease prevention in adults. http://www. uspreventiveservicestaskforce.org/uspstf/uspsphys.htm.

6. Ward E, Jemal A, Cokkinides V, Singh GK, Cardinez C, Ghafoor A, Thun M: Cancer disparities by race/ethnicity and socioeconomic status. CA Cancer J Clin 2004, 54(2):78-93.

7. Freeman HP: Poverty, culture, and social injustice: determinants of cancer disparities. CA Cancer J Clin 2004, 54(2):72-77.

8. Halle M, Lewis CB, Seshamani M: Health Disparities: A Case For Closing the Gap. In U.S. Department of Health and Human Services. Government: Health Reform; 2009.

9. The Affordable Care Act. http://www.whitehouse.gov/healthreform/ timeline.

10. Take healthcare into your own hands. http://www.healthcare.gov/ prevention/index.html.

11. IOM (Institute of Medicine): The Future of Nursing: Leading Change, Advancing Health. Washington, DC: The National Academies Press; 2011

12. Division of Medicine and Dentistry, Bureau of Health Professions, Health Resources and Services Administration, U.S. Department of Health and Human Services: Affordable Care Act: Expansion of Physician Assistant Training Program, Frequently Asked Questions; 2010. Revised July 8, 2010, on the Internet at: http://bhpr.hrsa.gov/grants/expansionfaq.pdf.

13. Grumbach K, Hart LG, Mertz E, Coffman J, Palazzo L: Who is caring for the underserved? A comparison of primary care physicians and nonphysician clinicians in California and Washington. Ann Fam Med 2003, 1(2):97-104.

14. Cooper RA: New directions for nurse practitioners and physician assistants in the era of physician shortages. Acad Med 2007, 82(9):827-828 
15. Park M, Cherry D, Decker SL: Nurse practitioners, certified nurse midwives, and physician assistants in physician offices. NCHS Data Brief 2011, 69:1-8.

16. Bureau of Labor Statistics, U.S. Department of Labor: Occupational Outlook Handbook, 2012-2013 Edition, Physician Assistants. on the Internet at http://www.bls.gov/ooh/healthcare/physician-assistants.htm.

17. Yarnall KS, Pollak Kl, Ostbye T, Krause KM, Michener JL: Primary care: is there enough time for prevention? Am J Public Health 2003, 93(4):635-641.

18. Wagner EH: Chronic disease management: what will it take to improve care for chronic illness? Eff Clin Pract 1998, 1(1):2-4.

19. Wagner $\mathrm{EH}$ : The role of patient care teams in chronic disease management. BMJ 2000, 320(7234):569-572.

20. Wagner EH, Austin BT, Von Korff M: Organizing care for patients with chronic illness. The Milbank quarterly 1996, 74(4):511-544.

21. Coleman K, Austin BT, Brach C, Wagner EH: Evidence on the chronic care model in the new millennium. Health Aff 2009, 28(1):75-85.

22. Yabroff KR, Kerner JF, Mandelblatt JS: Effectiveness of interventions to improve follow-up after abnormal cervical cancer screening. Prev Med 2000, 31(4):429-439.

23. Mandelblatt J, Armetta C, Yabroff KR, Liang W, Lawrence W: Descriptive review of the literature on breast cancer outcomes, through 2000. J Nat/ Cancer Inst Monogr 1990, 2004(33):8-44.

24. Menees SB, Patel DA, Dalton V: Colorectal cancer screening practices among obstetrician/gynecologists and nurse practitioners. J Women's Health 2009, 18(8):1233-1238.

25. Patton LL, Ashe TE, Elter JR, Southerland JH, Strauss RP: Adequacy of training in oral cancer prevention and screening as self-assessed by physicians, nurse practitioners, and dental health professionals. Oral Surg Oral Med Oral Pathol Oral Radiol Endod 2006, 102(6):758-764.

26. Hopkins SC, Lenz ER, Pontes NM, Lin SX, Mundinger MO: Context of care or provider training: the impact on preventive screening practices. Prev Med 2005, 40(6):718-724

27. Lin SX, Gebbie KM, Fullilove RE, Arons RR: Do nurse practitioners make a difference in provision of health counseling in hospital outpatient departments? J Am Acad Nurse Pract 2004, 16(10):462-466.

28. Sansbury LB, Klabunde CN, Mysliwiec P, Brown ML: Physicians' use of nonphysician healthcare providers for colorectal cancer screening. Am $J$ Prev Med 2003, 25(3):179-186

29. Oliveria SA, Altman JF, Christos PJ, Halpern AC: Use of nonphysician health care providers for skin cancer screening in the primary care setting. Prev Med 2002, 34(3):374-379.

30. Shaheen NJ, Crosby MA, O'Malley MS, Murray SC, Sandler RS, Galanko JA, Ransohoff DF, Klenzak JS: The practices and attitudes of primary care nurse practitioners and physician assistants with respect to colorectal cancer screening. Am J Gastroenterol 2000, 95(11):3259-3265.

31. Murphy PA: Primary care for women. Health assessment, health promotion, and disease prevention services. J Nurse Midwifery 1996, 41(2):83-91.

32. Zahnd EG, Coates TJ, Richard RJ, Cummings SR: Counseling medical patients about cigarette smoking: a comparison of the impact of training on nurse practitioners and physicians. Nurse Pract 1990, 15(3):10-13. 17-18.

33. Tompkins $\mathrm{TH}$, Belza B, Brown MA: Nurse practitioner practice patterns for exercise counseling. J Am Acad Nurse Pract 2009, 21(2):79-86.

34. Kawamoto K, Houlihan CA, Balas EA, Lobach DF: Improving clinical practice using clinical decision support systems: a systematic review of trials to identify features critical to success. BMJ 2005, 330(7494):765.

35. Price JH, Jordan TR, Dake JA: Perceptions and use of smoking cessation in nurse-midwives' practice. J Midwifery Womens Health 2006, 51(3):208-215.

36. Running A, Kipp C, Mercer V: Prescriptive patterns of nurse practitioners and physicians. J Am Acad Nurse Pract 2006, 18(5):228-233.

37. Moody NB, Smith PL, Glenn LL: Client characteristics and practice patterns of nurse practitioners and physicians. Nurse Pract 1999, 24(3):94-96. 99-100, 102-103.

38. Gebauer C, Kwo CY, Haynes EF, Wewers ME: A nurse-managed smoking cessation intervention during pregnancy. J Obstet Gynecol Neonatal Nurs 1998, 27(1):47-53.

39. Mandelblatt J, Traxler M, Lakin P, Thomas L, Chauhan P, Matseoane S, Kanetsky P: A nurse practitioner intervention to increase breast and cervical cancer screening for poor, elderly black women. The Harlem study team. J Gen Intern Med 1993, 8(4):173-178.
40. Newhouse RP, Stanik-Hutt J, White KM, Johantgen M, Bass EB, Zangaro G, Wilson RF, Fountain L, Steinwachs DM, Heindel L, et al: Advanced practice nurse outcomes 1990-2008: a systematic review. Nurs Econ 2011, 29(5):230-250. quiz 251.

41. Cancer Screening in the United States. http://www.cdc.gov/cancer/ colorectal/what cdc is doing/screening_us.htm.

42. Donelan K, DesRoches CM, Dittus RS, Buerhaus P: Perspectives of physicians and nurse practitioners on primary care practice. N Engl J Med 2013, 368(20):1898-1906.

43. Halpern MT, Ward EM, Pavluck AL, Schrag NM, Bian J, Chen AY: Association of insurance status and ethnicity with cancer stage at diagnosis for 12 cancer sites: a retrospective analysis. Lancet Oncol 2008, 9(3):222-231.

44. Taplin SH, Ichikawa L, Yood MU, Manos MM, Geiger AM, Weinmann S, Gilbert J, Mouchawar J, Leyden WA, Altaras R, et al: Reason for late-stage breast cancer: absence of screening or detection, or breakdown in follow-up? J Natl Cancer Inst 2004, 96(20):1518-1527.

45. Leyden WA, Manos MM, Geiger AM, Weinmann S, Mouchawar J, Bischoff K Yood MU, Gilbert J, Taplin SH: Cervical cancer in women with comprehensive health care access: attributable factors in the screening process. J Natl Cancer Inst 2005, 97(9):675-683.

46. The Power to Prevent, The Call to Control: At A Glance. 2009. http:// www.cdc.gov/chronicdisease/resources/publications/aag/chronic.htm.

47. Korenstein D, Falk R, Howell EA, Bishop T, Keyhani S: Overuse of health care services in the United States: an understudied problem. Arch Intern Med 2012, 172(2):171-178.

48. Kale MS, Bishop TF, Federman AD, Keyhani S: Trends in the overuse of ambulatory health care services in the United States. JAMA Internal Medicine 2013, 173(2):142-148.

49. Chassin MR, Galvin RW: The urgent need to improve health care quality. Institute of Medicine National Roundtable on Health Care Quality. JAMA 1998, 280(11):1000-1005.

50. Berry JA: Nurse practitioners' use of clinical preventive services. J Am Acad Nurse Pract 2009, 21(8):454-460.

doi:10.1186/1472-6963-14-68

Cite this article as: Smith et al: Advanced practice registered nurses, physician assistants and cancer prevention and screening: a systematic review. BMC Health Services Research 2014 14:68.

\section{Submit your next manuscript to BioMed Central and take full advantage of:}

- Convenient online submission

- Thorough peer review

- No space constraints or color figure charges

- Immediate publication on acceptance

- Inclusion in PubMed, CAS, Scopus and Google Scholar

- Research which is freely available for redistribution 